\title{
Aspirasi Pemuda Kelas Bawah dan Reproduksi Sosial di Jawa Tengah
}

\author{
Oki Rahadianto Sutopo, Rani Dwi Putri, Karina Larasati Kusumawardhani \\ Youth Studies Centre (YouSure) FISIPOL UGM \\ oki.rahadianto@ugm.ac.id | raniedwi67@gmail.com | karlarasati@gmail.com
}

\section{ABSTRAK}

Jawa Tengah adalah salah satu provinsi yang progresif dalam mengembangkan industri terutama di bidang manufaktur. Namun, angka pengangguran di kalangan pemuda di provinsi ini justru terhitung cukup tinggi. Tingginya angka pengangguran dan rendahnya tingkat partisipasi dalam pasar tenaga kerja di kalangan pemuda disebabkan oleh berbagai faktor. Salah satunya adalah gap antara Sumber Daya Manusia dengan permintaan di pasar tenaga kerja. Kesenjangan pendidikan, skill, dan akses informasi menjadi pemicu tidak tersaringnya pemuda dalam pasar kerja. Kesenjangan ini didasari oleh perbedaan kelas sosial yang melekat pada setiap pemuda. Selain itu, faktor perbedaan gender juga mempengaruhi kesempatan serta kebebasan dalam memilih pekerjaan. Penelitian ini menggunakan metode kualitatif dengan proses observasi, wawancara mendalam, dan Focus Group Discussion (FGD) sebagai teknik pengumpulan data. Melalui purposive sampling 2 informan perempuan dan 2 informan laki-laki, penelitian ini menyimpulkan bahwa faktor kelas sosial, gender, dan konteks yang berubah terutama dalam kondisi Labour Market Flexibility (LMF) menjadi faktor utama dalam membentuk dan memengaruhi proses transisi dan aspirasi masa depan pemuda. Penerapan neoliberalisme dan Labour Market Flexibility justru melanggengkan reproduksi sosial berdasarkan kelas dan gender yang memungkinkan kesenjangan sosial akan semakin meningkat di masa depan. Kondisi ini akan semakin meminggirkan kaum muda miskin dan rentan.

\section{KATA KUNGI Pemuda | Gender | Kelas Sosial | LMF | Transisi | Aspirasi Masa Depan}

\section{PENDAHULUAN}

Proses transisi dari domain pendidikan ke dunia kerja serta aspirasi masa depan merupakan subjek penting dalam kajian kepemudaan. Dalam bidang kepemudaan dan ketenagakerjaan, pemerintah Indonesia tengah berupaya untuk menurunkan angka pengangguran, dimana dalam Rencana Kerja Pemerintah (RKP) 2018 disebutkan bahwa target pengangguran berada di sekitar 5 - 5,3 persen (Bappenas 2010). Merial Institute mempublikasikan hasil kajian pembangunan kepemudaan nasional 2017 dan menyatakan bahwa jumlah generasi muda Indonesia meningkat, namun angka pengangguran bertambah. Data BPS 2016 mencatat jumlah pemuda Indonesia mencapai 62.061.400 jiwa. Namun ternyata dalam kurun 3 tahun dari 2012-2015 pengangguran pemuda cenderung meningkat, padahal potensi yang dimiliki dalam menggerakkan aktivitas ekonomi sangat besar (Indrawan 2017) Terjadinya peningkatan jumlah generasi muda ini pun berdampak terhadap perubahan pola dan minat lapangan pekerjaan di sektor-sektor ekonomi tertentu.

\begin{tabular}{|c|c|c|c|c|c|c|}
\hline \multirow[b]{2}{*}{ Karakteristik } & \multicolumn{5}{|c|}{ Jenis Kegiatan } & \multirow[b]{2}{*}{ Total } \\
\hline & Bekerja & $\frac{\text { Pengang- }}{\text { guran }}$ & Sekolah & \begin{tabular}{|c|} 
Mengurus \\
Rumah \\
Tangga \\
\end{tabular} & Lainnya & \\
\hline (1) & (2) & (3) & (4) & (5) & (6) & (7) \\
\hline Total Pemuda & 51,47 & 8,39 & 20,08 & 17,62 & 2,43 & 100,00 \\
\hline \multicolumn{7}{|l|}{ Tipe Daerah } \\
\hline Perkotaan & 50,19 & 9,50 & 22,70 & 15,25 & 2,36 & 100,00 \\
\hline Perdesaan & 53,18 & 6,91 & 16,57 & 20,81 & 2,53 & 100,00 \\
\hline \multicolumn{7}{|l|}{ Jenis Kelamin } \\
\hline Laki-laki & 63,10 & 10,09 & 20,36 & 2,86 & 3,60 & 100,00 \\
\hline Perempuan & 39,47 & 6,65 & 19,80 & 32,86 & 1,23 & 100,00 \\
\hline \multicolumn{7}{|l|}{ Kelompok Umur } \\
\hline 16-18 tahun & 19,95 & 8,03 & 60,07 & 8,62 & 3,32 & 100,00 \\
\hline 19-24 tahun & 54,43 & 12,34 & 13,35 & 17,05 & 2,83 & 100,00 \\
\hline 25-30 tahun & 69,12 & 4,61 & 0,73 & 24,11 & 1,44 & 100,00 \\
\hline \multicolumn{7}{|c|}{ Sumber: BPS - Sakernas Agustus 2017} \\
\hline Tabel 1 & $\begin{array}{l}\text { Persent } \\
\text { dalam }\end{array}$ & $\begin{array}{l}\text { ase Pemu } \\
\text { Seminggu }\end{array}$ & $\begin{array}{l}\text { Ida men } \\
\text { u Terak }\end{array}$ & $\begin{array}{l}\text { ut Jenis } \\
\text { r, } 2017\end{array}$ & Kegiatan & \\
\hline
\end{tabular}

Jurnal Studi Pemuda 7(1), 2018

www.jurnal.ugm.ac.id/jurnalpemuda 
Tabel 1 di atas mengindikasikan tiga hal penting mengenai kondisi ketenagakerjaan pemuda di Indonesia pada tahun 2017. Pertama, separuh dari pemuda Indonesia bekerja, yaitu 51,47 persen. Kedua, pola ini terlihat baik di perkotaan maupun pedesaan, dimana persentase pemuda yang bekerja pun mencapai separuh dari populasi di tiap tipe daerah. Namun, terdapat perbedaan sebesar 2,59 persen pada jumlah pengangguran dimana pemuda di kota angkanya cenderung lebih tinggi jika dibandingkan dengan pemuda yang tinggal di pedesaan. Ketiga, tabel di atas juga menunjukkan persentase pemuda laki-laki yang bekerja lebih tinggi angkanya dibandingkan dengan pemuda perempuan. Perbedaannya pun cukup signifikan dimana jumlah pemuda perempuan yang bekerja hanya setengah dari total pemuda laki-laki yang bekerja. Di sisi yang lain, untuk kegiatan mengurus rumah tangga, terlihat persentase pemuda perempuan jauh lebih tinggi dibandingkan pemuda laki-laki. Hal ini mengindikasikan bahwa pemuda laki-laki cenderung memutuskan untuk bekerja atau mencari pekerjaan dalam rentang usia produktifnya, sedangkan pemuda perempuan cenderung memilih untuk mengurus rumah tangga.

Dalam konteks transisi pemuda dari domain pendidikan ke kerja (Furlong and Cartmel 2007), faktor pendidikan juga tidak dapat dilepaskan dari tingkat pengangguran dan kondisi ketenagakerjaan pemuda Indonesia. Kaum muda dengan tingkat pendidikan rendah (SD maupun SMP) masih memiliki tingkat pengangguran yang tinggi (20 persen) jika dibandingkan dengan tingkat pengangguran kaum muda lulusan vokasi maupun perguruan tinggi (5-7 persen). Mayoritas kaum muda lulusan pendidikan dasar didominasi oleh mereka yang berasal dari kelas bawah. Dalam konteks neoliberalisme, pemuda dituntut untuk terus meningkatkan kualifikasi pendidikannya hingga ke level universitas dan juga menambah skill-skill yang relevan dengan harapan akan semakin meningkatkan peluang untuk melakukan mobilitas sosial ke atas dalam pekerjaan. Namun hal tersebut tidak pernah berlaku secara linear, Furlong and Cartmel (2007) dan Woodman and Wyn (2015) misalnya berdasarkan kasus di Inggris dan
Australia menjelaskan bahwa keberhasilan menempuh pendidikan tinggi tidak menjamin pemuda mendapatan pekerjaan; yang terjadi justru semakin banyaknya pengangguran terdidik, pemuda yang bekerja di bawah kualifikasi pendidikannya dan jebakan pada sistem kerja kontrak, kasual tanpa jaminan untuk melakukan progress karir.

Dalam diskursus kebijakan kepemudaan, masalah pengangguran seringkali digeneralisir hanya berdasarkan data statistik yang terukur. Jika ditarik benang merahnya, titik tekan kesenjangan antara pasar kerja dengan kondisi produktivitas angkatan kerja muda, keterampilan, dan pendidikan juga menjadi faktor utama tingginya angka pengangguran kaum muda. Lebih lanjut, pemetaan permasalahan tersebut tidak dapat mengesampingkan aspek struktural, sosial dan kultural yang terjadi di setiap daerah dengan karakteristiknya masing-masing.; dengan kata lain, sensitifitas akan konteks merupakan faktor penting dalam memahami transisi pemuda dan aspirasi masa depan. Menurut France and Roberts (2017), untuk memahami mengenai isu kesenjangan, aspek kelas sosial dan gender perlu ditelisik lebih dalam. Hal ini dikarenakan baik kelas sosial maupun gender secara tidak langsung berpengaruh terhadap aspirasi, imajinasi, penentuan keputusan kaum muda mengenai masa depan, termasuk peluang keberhasilan untuk mewujudkan cita-cita ideal tersebut. Reproduksi kesenjangan sosial yang semakin meningkat dikhawatirkan akan semakin meminggirkan kaum muda miskin dan rentan (Allen 2016). Dengan menggunakan contoh kasus pemuda kelas bawah di Jawa Tengah, artikel ini akan mengeksplor secara mendalam mengenai aspirasi masa depan pemuda serta bagaimana kelas sosial, gender, dan konteks yang berubah saling berkelindan satu sama lain dalam menciptakan reproduksi sosial.

\section{STUDI-STUDI TERDAHULU MENGENAI PEMUDA DAN ASPIRASI MASA DEPAN}

Dalam konteks produksi pengetahuan di Indonesia, kajian kepemudaan (youth studies) masih dapat digolongkan sebagai kajian interdisiplin yang relatif baru. Kondisi objektif ini dalam level tertentu berbeda dengan produksi pengetahuan mengenai 
kepemudaan di Inggris, Australia dan Amerika yang telah mapan dalam mengembangkan dan merawat youth studies. Terlepas dari kesenjangan produksi pengetahuan tersebut, argumen dalam artikel ini memposisikan dirinya untuk melengkapi beberapa studi-studi terdahulu terpilih mengenai pemuda dan aspirasi masa depan, antara lain: Nilan et al (2011), Nilan and Artini (2013) dan Naafs (2018). Di bawah ini disajikan review singkat terhadap studi-studi terdahulu dan novelty dari argumen penulis dalam artikel ini.

Nilan et al (2011) mendasarkan dari hasil survei di beberapa provinsi di Indonesia menjelaskan bahwa aspirasi masa depan pemuda di Indonesia masih diwarnai optimisme. Tumbuh dan berkembang dalam konteks pertumbuhan ekonomi dan melesatnya jumlah kelas menengah, pemuda Indonesia melihat keberhasilan menempuh pendidikan tinggi menjadi salah satu indikator penting keberhasilan masa depan. Selain itu, pendidikan tinggi juga berkaitan erat dengan aspirasi masa depan terkait dengan pekerjaan terutama cita-cita ideal untuk bekerja di perusahaan, dengan kata lain, pemuda Indonesia mengindikasikan pekerjaan sebagai profesi yang menjanjikan progress karir. Di sisi yang lain, dengan menempatkan pendidikan dan karir sebagai aspirasi ideal, bukan berarti pemuda Indonesia menjadi lebih terindividualisasi. Menurut Nilan et al (2011), membangun rumah tangga dan memiliki anak juga masih menjadi hal yang penting di masa depan. Menurut Nilan et al (2011) kelas masih menjadi faktor penting dalam menentukan peluang pemuda di masa depan. Bagi pemuda dari kelas menengah, hambatan untuk menggapai aspirasi ideal masa depan adalah kurangnya motivasi sedangkan bagi pemuda dari kelas bawah, faktor ekonomi dan kurangnya jaringan sosial menjadi hambatan utama.

Dalam kasus yang berbeda, Nilan and Artini (2013) melakukan studi mengenai aspirasi masa depan pemuda Bali yang bekerja di kapal pesiar. Pemuda Bali dari background kelas bawah dan menengah-bawah mempunyai motivasi yang tinggi untuk bekerja di kapal pesiar karena dianggap akan memperbaiki kualitas hidup dirinya sekaligus keluarganya di masa depan. Namun setelah bekerja di kapal pesiar, pemuda Bali harus mengalami kekecewaan karena sistem kerja yang eksploitatif antara lain terkait jam kerja yang tinggi, mengalami kekerasan simbolik dan terjerat hutang. Pemuda Bali yang bekerja di kapal pesiar tidak menyarankan anggota keluarganya yang lain untuk mengalami eksploitasi seperti mereka. Setelah bekerja di kapal pesiar, banyak pemuda Bali yang tidak mampu melakukan mobilitas sosial dari kelas bawah ke kelas menengah, justru yang terjadi adalah reproduksi sosial. Salah satunya dikarenakan lilitan hutang dan tuntutan untuk mengirimkan remittances kepada keluarga luas (extended family) mereka. Di sisi yang lain, pemuda Bali yang telah bekerja di kapal pesiar selama 10-12 tahun mempunyai aspirasi masa depan untuk menjalankan wirausaha. Namun mereka belum mempunyai skillskill yang memadai dan relevan untuk menjadi wirausaha dan mengembangkan bisnis yang dicita-citakannya.

Berdasarkan penelitian mengenai transisi pemuda di Cilegon, Jawa Barat, Naafs (2018) menjelaskan bahwa pada umumnya pemuda Cilegon dari kelas menengah-bawah optimistik dalam memandang mengenai aspirasi masa depan. Namun optimisme tersebut juga dibarengi dengan tuntutan untuk dapat memenuhi kebutuhan hidup sehari-hari baik berupa kebutuhan pokok maupun dalam hal gaya hidup. Pemuda Cilegon menegosiasikan antara kebutuhan sehari-hari dan gaya hidup dengan tuntutan dan ekspektasi dari keluarga mereka baik nuclear maupun extended, bukan didasarkan pada pilihan dan kebebasan individual. Naafs (2018) menjelaskan bahwa di tengah-tengah sulitnya mendapatkan pekerjaan yang permanen dan kurangnya jaringan sosial, pemuda Cilegon dari kelas menengah-bawah tetap mempunyai aspirasi masa depan untuk menyamai standar nasional dan global kehidupan pemuda dari kelas menengah serta kelas atas. Berdasarkan studi-studi terdahulu yang telah direview, artikel mengenai aspirasi pemuda di Jawa Tengah ini melengkapi tidak hanya melalui highlight terhadap relevannya kelas sosial (France and Roberts 2017) dalam menentukan aspirasi dan peluang keberhasilan pemuda di masa depan. Namun artikel ini juga menawarkan mengenai relevannya gender (Wyn et al 2017) dalam 
pembentukan aspirasi pemuda sekaligus bagaimana kedua aspek tersebut berinteraksi secara dialektis dan beririsan dengan konteks yang berubah (Sutopo 2014; Woodman and Wyn 2015) terutama neoliberalisme dan Labour Market Flexibility (LMF) dalam meneguhkan reproduksi dan kesenjangan sosial di Jawa Tengah.

\section{METODE PENELITIAN}

Penelitian ini menggunakan pendekatan kualitatif dan memfokuskan pada isu mengenai angkatan kerja muda dengan lingkup wilayah Jawa Tengah khususnya Kabupaten Semarang, Kabupaten Demak, dan Kota Semarang. Menurut Leavy (2014), penelitian kualitatif merupakan cara yang digunakan untuk membangun, mengeksplorasi, menggambarkan, atau menjelaskan fenomena, pengetahuan sosial, dan pengalaman manusia. Dalam proses pengumpulan data, penelitian ini menggunakan teknik in-depth interview, observasi, dan FGD. Observasi digunakan untuk memahami fenomena awal yang menyangkut subjek penelitian baik secara langsung maupun tidak langsung, serta untuk mendapatkan gambaran mengenai kondisi sosial, ekonomi, budaya subjek dalam ranah kehidupan sehari-hari. Sedangkan wawancara mendalam digunakan untuk mendapatkan informasi secara utuh dan detail dari setiap informan, termasuk dalam menggali narasi biografis, critical moments (Thomson et al 2002) serta proses interpretasi dan reintepretasi subjek mengenai pengalaman transisi baik di domain pendidikan, keluarga, dan pekerjaan (Heath et al 2009). Penelitian ini juga memanfaatkan FGD untuk mendapatkan informasi mengenai masalah, hambatan, maupun harapan yang dihadapi terkait dengan isu ketenagakerjaan secara umum.

Informan dalam penelitian ini difokuskan pada pemuda yang masuk dalam kategori miskin dengan status pengangguran atau berpendapatan namun kurang dari 2 USD per hari. Informan yang diambil adalah 2 pemuda dan 2 pemudi yang masing-masing berasal dari 3 wilayah, yaitu Kabupaten Demak, Kota Semarang, dan Kabupaten Semarang. Keputusan dalam penentuan informan berdasarkan pada teknik purposive sampling. Pemilihan keempat informan ini ditujukan untuk menjawab masalah penelitian, yaitu bagaimana persoalan kelas, gender, dan konteks yang berubah berinteraksi secara dialektik dalam membentuk orientasi masa depan para pemuda. Dalam proses pengumpulan data, ketiga peneliti melakukan wawancara di lokasi yang berbeda sesuai kesepakatan dengan informan. Dalam proses wawancara, peneliti telah meminta izin dan mendapatkan persetujuan dari informan untuk merekam serta menuliskan dalam laporan riset serta artikel ilmiah.

\section{MENEMPATKAN DALAM KONTEKS: LABOUR MARKET FLEXIBILITY DI INDO- NESIA}

Ide-ide mengenai neoliberalisme menjadi wacana global yang dominan dalam berbagai ranah kehidupan termasuk dalam aspek subjektivitas pemuda (Kelly 2006). Turken et al (2016) mengungkapkan bahwa neoliberalisme telah lebih jauh dikonseptualisasikan sebagai wacana global yang bersifat hegemonik sehingga secara sadar maupun tidak sadar mampu membentuk akal sehat manusia. Dalam berbagai bidang kehidupan seperti pendidikan hingga pasar kerja, pemuda terpapar dengan perubahan wacana dan ideologi baik tingkat lokal, nasional, maupun global yang sangat mungkin memengaruhi perkembangan mereka. Dengan kata lain, perkembangan pemuda baik dalam aspek "transition" maupun "culture" tidak dapat terlepas dari konteks sosial, budaya, ekonomi dan politik serta perubahan sosial yang melingkupinya (Sutopo 2014; Woodman and Wyn 2015).

Dalam praktiknya, neoliberalisme meyakini tiga pilar yaitu liberalisasi, deregulasi, dan privatisasi. Oleh karena itu, negara yang menganut ideologi neoliberalisme dikonstruksikan lebih mementingkan hak-hak milik pribadi individu, aturan hukum, dan pranata-pranata pasar serta perdagangan bebas (Harvey 2009). Gagasan inilah yang gencar disuarakan oleh negara-negara maju dan diikuti oleh negara-negara berkembang, termasuk Indonesia. Dalam domain ketenagakerjaan, gagasan neoliberalisme terealisasikan dalam konsep Labour Market Flexibility (LMF) di mana hubungan antara pemberi pekerjaan dan pekerja didasari atas azas kebebasan. Para 
pekerja dianggap bebas menyalurkan tenaga dan emosi sesuai dengan kebutuhan, begitu juga dengan pemberi pekerjaan yang bebas membeli tenaga kerja sesuai keuntungan perusahaan. Hal ini tercermin dalam Undang-undang No. 13 Tahun 2003 yang mengatur tentang Ketenagakerjaan. Semangat kebebasan dalam pasar tenaga kerja salah satunya ditandai dengan sistem kontrak yang didasarkan pada kesukarelaan. Dalam Undang-undang Ketenagakerjaan tertulis pada Pasal 58 dan 59 yang mengisyaratkan adanya penerapan Sistem Perjanjian Kerja Waktu Tertentu (PKWT). Sistem ini mampu memberikan si pemberi kerja untuk menentukan jenis pekerjaan sesuai dengan kebutuhan dan keuntungan perusahaan. Jenis pekerjaan biasanya bersifat musiman, sementara, maupun tidak tetap sehingga sistem ini cenderung memberikan celah bagi pemberi pekerjaan untuk meniadakan beberapa aspek yang menjadi hak pekerja, seperti tunjangan, kompensasi kecelakaan kerja, uang pensiunan, dan pesangon. $\mathrm{Na}^{-}$ mun, bagi para pendukung konsep Labour Market Flexibility (LMF), para pekerja mendapatkan jenis gratifikasi lain dari pekerjaan tersebut, seperti persahabatan, pengakuan sosial, status, tugas pekerjaan yang secara intrinsik menguntungkan, pengayaan hidup mereka, pengalaman atau pengembangan potensi pribadi mereka (Purdy 1988: p. 5). Pada tataran inilah, kedua pihak dikonstruksikan dapat mencapai titik keseimbangan.

Dalam kenyataannya, kebebasan yang ditawarkan oleh konsep Labour Market Flexibility tidak pernah terjadi. Dalam pandangan neoliberalisme, tenaga kerja tidak diartikan sebagai sesuatu yang bersifat objektif. Namun mereka dianggap sebagai seorang pengusaha yang menjual tenaganya kepada para pemberi kerja secara sukarela. Selain tenaga, aspek seperti pendidikan, keterampilan, maupun pengetahuan menjadi modal yang akan memberikan nilai lebih tinggi dalam bentuk upah. Oleh karena itu, para pekerja diasumsikan sebagai manusia yang mandiri, independen dan berdaya dalam pusaran pasar bebas. Namun dalam realitas empiris implikasi dari LMF menghasilkan persaingan yang tidak setara. Modal sosial, ekonomi, budaya, maupun akses informasi yang terdistribusi secara tidak merata menciptakan pasar yang bersifat memihak, terutama pada pemuda yang mempunyai on-hand stock of capital yang relevan dengan permintaan pasar kerja. Studi komparasi yang dilakukan oleh France dan Roberts (2017) di Inggris, Australia dan New Zealand misalnya menjelaskan mengenai masih relevannya kelas sosial sebagai faktor penentu dalam proses transfer kapital baik ekonomi, sosial, dan budaya bagi pemuda untuk mendapatkan kesempatan yang lebih besar dalam mendapatkan pekerjaan.

Dalam konteks LMF, generasi muda merupakan subjek yang paling terpengaruh terhadap penerapan kebijakan tersebut; dengan kata lain, sebagaimana dijelaskan oleh Standing (2014), pemuda menjadi "The Precariat: the New Dangerous Class". Namun generasi muda Indonesia bukanlah satusatunya generasi yang terancam risiko dan ketidakpastian masa depan; fenomena ini terjadi secara global baik pemuda dari belahan dunia Selatan maupun Utara (Andres and Wyn 2010; Dwyer et al 2018). Dalam perspektif transisi pemuda, ketidakpastian dalam transisi di dunia kerja akan berdampak pada proses transisi pemuda pada domain yang lain misalnya, menuju domain pernikahan, mempunyai anak, maupun untuk memiliki rumah sendiri. Dengan kata lain, generasi muda dalam jebakan LMF akan menghadapi masa depan dengan risiko-risiko ketidakpastian yang semakin sulit untuk diprediksi dan diantisipasi (Sutopo dan Meiji 2014; Woodman, Threadgold, and Inesedy 2015).

Konteks Jawa Tengah

Dalam konteks Jawa Tengah di tahun 2017 jumlah pemuda dengan rentang usia 16-30 tahun mencapai sekitar 7,8 juta jiwa (BPS 2017). Berdasarkan data, diperkirakan sekitar 2,8 juta pemuda hidup dalam kemiskinan dan sekitar 1,5 juta di antaranya berstatus sebagai pengangguran (Utari 2018). Kemiskinan dan pengangguran di Jawa Tengah memang masih tergolong tinggi. Badan Pusat Statistik (2018) mencatat persentase angka kemiskinan di Jawa Tengah pada tahun 2017 masih mencapai 11,32 persen atau 3,89 juta jiwa dari seluruh penduduk. Sedangkan Tingkat Pengangguran Terbuka (TPT) berada pada angka 4,57 persen dari 18,01 juta 
angkatan kerja yang tersedia. Angkatan kerja yang bekerja masih didominasi pada usia 35-54 tahun, sedangkan untuk usia yang masuk pada kategori pemuda, hanya sekitar 5,4 juta dari 17,1 juta angkatan kerja yang bekerja. Jumlah angkatan kerja yang bekerja berdasarkan usia ditunjukkan dalam tabel di bawah ini:

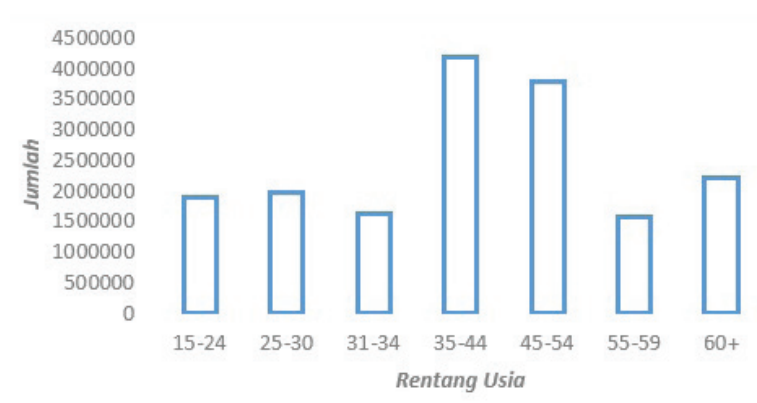

Tabel 1. Jumlah Angkatan Kerja yang Bekerja Berdasarkan Usia Provinsi Jawa Tengah Tahun 2017

Kecenderungan mengenai tingginya angka pengangguran pemuda di Jawa Tengah merupakan kondisi yang mengejutkan dikarenakan Jawa Tengah adalah salah satu provinsi yang progresif dalam mengembangkan industri terutama, di bidang manufaktur. BPS mencatat hingga tahun 2015 terdapat 4.378 perusahaan menengah dan besar yang tersebar di seluruh wilayah Jawa Tengah. Di mana 4.090 di antaranya adalah perusahaan milik swasta dan 240 perusahaan milik asing. Beberapa di antara perusahaan besar yang ada di Jawa Tengah antara lain: The Coca-Cola Com- pany, Nissin, Apacinti Corpora, PT. Sinar Sosro, P'T. Sido Muncul, dan PT. Morich Indo Fashion. Dari tahun ke tahun investasi terus meningkat, bahkan pada tahun 2018, nilai investasi telah mencapai Rp. 27,6 triliun (Kartika 2018). Dengan potensi ini, dalam kondisi yang ideal Provinsi Jawa Tengah seharusnya memiliki persentase pengangguran yang rendah dan tingkat partisipasi di pasar tenaga kerja yang tinggi terutama bagi pemuda, sebagai salah satu sumber daya manusia yang melimpah di Provinsi tersebut.

Namun, sebagaimana ditunjukkan pada data statistik di atas, angka pengangguran masih tinggi dan tingkat partisipasi dalam pasar tenaga kerja, terutama bagi pemuda, masih rendah. Kecenderungan ini disebabkan oleh berbagai macam faktor, salah satunya adalah rendahnya angka partisipasi mengindikasikan adanya gap antara Sumber Daya Manusia dengan apa yang menjadi permintaan di pasar tenaga kerja. Rendahnya pendidikan, skill, dan akses informasi juga menjadi pemicu tidak tersaringnya pemuda di pasar kerja. Dengan kondisi kesejahteraan yang masih rendah, pemuda juga cenderung sulit untuk mengakses pendidikan, layanan pelatihan, maupun informasi. Padahal dalam konteks Labour Market Flexibility (LMF), faktor pendidikan, skill, dan akses informasi serta jaringan sosial merupakan "modal" yang berkaitan dengan keberhasilan para pencari kerja dalam mendapatkan pekerjaan yang diinginkan. Dengan kata lain, semakin besar modal pemuda yang sesuai dengan rule of the game dalam Labour Market Flexibility (LMF) maka kecenderungan untuk berhasil dalam memanfaatkan kesempatan kerja juga semakin besar (Beck 2014). Di sisi yang lain, modal sosial dan modal budaya juga berpengaruh bagi pembentukan aspek subjektif pemuda dalam mempersepsikan, menegosiasikan, dan mengantisipasi risiko di masa depan terutama dalam konteks pekerjaan (Nilan et al 2011; Sutopo and Meiji 2014).

\section{MEMAHAMI TRANSISI DAN ASPIRASI MELALUI EMPAT NARASI PEMUDA}

Bagian ini menceritakan mengenai narasi empat pemuda dari Kabupaten Demak, Kota Semarang, dan Kabupaten Semarang dalam menjalani transisi dari domain pendidikan ke dunia kerja serta aspirasi mereka di masa depan. Narasi biografis pemuda menjadi pilihan yang tepat untuk memberikan lebih banyak ruang bagi aspek subjektif (pemaknaan) pemuda saat menjalani transisi dalam konteks yang berubah (Sutopo 2014; Woodman and Wyn 2015). Dengan berposisi bahwa transisi pemuda selalu bersifat relasional (Wyn and White 1997) maka aspek kelas sosial, gender, dan konteks menjadi perhatian dalam narasi biografis di bawah ini.

Anjarwati

Anjarwati merupakan anak bungsu dari empat bersaudara. Lahir dari keluarga miskin, ayahnya berprofesi sebagai kuli bangunan dengan status pekerja lepas dan ibunya adalah seorang ibu rumah tangga. Melalui profesinya sebagai kuli bangunan, ayah Anjarwati mendapatkan upah Rp.60 ribu per hari. Namun statusnya sebagai pekerja lepas, tidak 
menjamin pekerjaan datang setiap saat. Kondisi inilah yang membuat Anjarwati dan 3 saudaranya terpaksa putus sekolah. Kakak pertamanya menempuh pendidikan sampai jenjang Sekolah Menengah Pertama (SMP). Sedangkan kakak kedua dan ketiga hanya pada tingkat Sekolah Dasar (SD), hal ini sebagaimana dijelaskan dalam wawancara mendalam:

\begin{abstract}
"Waktu kae cah-cah wayae sekolah kan sekitar 4Oan mbak, 35 lah bayarane. Lah sakiki sedino 3 kg, sak iki nek dijupuk 3 kilo 30 ribu kan entek toh mbak. Lha digawe sekolah ra nyandak mbak. Yo kui seng doh wegah sekolah. Yo nek karepe bapake tak kongkon terus sekolah tekan SMP tapi doh ragelem." (Ayah Anjarwati, wawancara 2018)

[Waktu anak-anak masih sekolah sekitar 40an mbak, 35 lah gajinya. Lha kalau sehari 3 kg, diambil aja 3 kilo seharga 30 ribu kan jadi habis mbak. Kalau dibuat bayar sekolah kan tidak cukup. Ya anak-anak jadi tidak minat sekolah. Ya kalau keinginan bapaknya ya suruh sekolah semua sampai SMP tapi pada tidak mau]
\end{abstract}

Sebagai anak bungsu dan satu-satunya anak perempuan, Anjarwati sebenarnya mempunyai akses untuk melanjutkan ke jenjang Sekolah Menengah Atas (SMA). Hal ini dikarenakan ketiga kakaknya telah bekerja sehingga dapat membantu ekonomi keluarga, termasuk memenuhi biaya sekolah Anjarwati. Namun, Anjarwati memilih untuk putus sekolah dan memutuskan untuk bekerja di sebuah pabrik. Alasannya sangat sederhana, Anjarwati lebih ingin mencari pengalaman kerja daripada harus melanjutkan sekolah ke jenjang yang lebih tinggi.

Setelah lulus SMP, Ajarwati bekerja di pabrik Wallet yang terletak tidak jauh dari rumahnya, yaitu Kecamatan Bergas, Kabupaten Semarang. Pada pengalaman pertamanya bekerja, Anjarwati mendapat upah kurang lebih 200 ribu per minggu dengan durasi 6 hari kerja. Dengan upah yang kecil dan jam kerja yang panjang tersebut tidak memungkinkan Anjarwati untuk membayangkan prospek kerja dan jenjang karir selanjutnya di pabrik tersebut. Oleh karena itu, setelah bekerja selama 2 bulan di pabrik Wallet, Anjarwati memutuskan untuk kejar paket C. Keputusan tersebut didasari oleh keinginannya untuk bekerja di sebuah pabrik besar yang mensyaratkan karyawannya memiliki ijazah tingkat SMA.
Perempuan yang berusia 19 tahun ini memang bercita-cita bekerja di pabrik besar dengan gaji tetap setiap bulannya. Cita-cita Anjarwati ini juga sangat didukung oleh ayahnya. Menurut ayah Anjarwati, dengan bekerja di pabrik besar bisa memiliki gaji yang terjamin untuk setiap bulannya. Terlebih, banyak pabrik besar seperti Pabrik Cimori dan Pabrik Garmen yang berposisi tidak jauh dari rumahnya sehingga memungkinkan diakses secara mudah dan spasial. Keinginan Anjarwati untuk bekerja di pabrik besar juga tidak luput dari kondisi sosio kultural lingkungan di sekitar rumahnya. Banyak perempuan seusianya dianggap "mapan" jika telah bekerja di sebuah pabrik besar.

Statusnya sebagai anak bungsu dan perempuan, di satu sisi Anjarwati mendapat sedikit keistimewaan, di sisi lain, ia juga mendapat hambatan untuk mobilitas sosial. Status anak bungsu sekaligus perempuan membuat Anjarwati tidak bisa leluasa memilih kota tujuan untuk bekerja, dengan kata lain, hambatan tersebut mempersempit akses pekerjaan baik secara spasial maupun dalam hal karir. Anjarwati hanya diperbolehkan oleh keluarganya untuk bekerja di daerah yang tidak jauh dari rumahnya, dimana ruang sosial tersebut memungkinkannya untuk berangkat di pagi hari dan pulang ke rumah di sore harinya.

Wahyu

Wahyu adalah pemuda yang berasal dari sebuah desa bernama Gintungan di Kabupaten Semarang. Ia terlahir dari ayah yang berprofesi sebagai kepala dusun dan ibu yang bekerja sebagai pedagang. Kondisi ekonomi keluarga yang cukup mampu mengantarkan Wahyu pada hingga jenjang pendidikan SMA. Setelah lulus, ia bekerja sebagai tukang kebun, namun hanya bertahan selama tiga minggu. Hal ini disebabkan oleh ketidakkonsistenan shift kerja yang didapatkan selama bulan puasa. Setelah mengundurkan diri dari pekerjaan tersebut, Wahyu bekerja di sebuah kafe milik temannya. Namun, juga tidak bertahan lama dengan alasan kegiatan di Gerakan Pemuda Ansor yang mengharuskannya sering pulang-pergi, membagi waktu antara bekerja dan kegiatan berorganisasi. 
Wahyu sudah lama menjadi anggota aktif di organisasi Gerakan Pemuda Ansor (GP Ansor), sebuah organisasi kemasyarakatan yang berafiliasi dengan Nahdlatul Ulama (NU). Hampir semua kegiatan GP Ansor yang berbasis di Kabupaten Semarang selalu ia ikuti. Bahkan seringkali ia lebih mementingkan kegiatan di GP Ansor dibandingkan dengan pekerjaannya. Sehingga bisa dikatakan ia sangat "loyal" pada organisasi yang ia ikuti sekarang ini, sebagaimana dijelaskan dalam wawancara mendalam:

“... kemah bakti ansor, nek misale kerjo, waktune terikat nek ono iki, kegiatan iki duh kok eman-eman, maksude kan tambah konco, kulo kan senenge ngono," (Wahyu, wawancara 2018)

[... kemah bakti ansor, kalau misal kerja, waktunya terikat kalau ada kegiatan kan sayang, maksudnya kan itu bisa menambah teman, saya sukanya itu]

Namun di sisi yang lain, loyalitasnya pada organisasi GP Ansor menghambat karir kerjanya. Hal ini diungkapkan oleh ayah Wahyu, "Nek sosial aktif mas, ning nek golek gawean mboten aktif [Kalau sosial aktif, tapi kalau mencari pekerjaan tidak aktif]" (Ayah Wahyu, wawancara 2018). Lebih lanjut tekanan dari ayahnya untuk mendapatkan pekerjaan ini juga dijelaskan oleh Wahyu sebagai berikut:

"Nggih dusun (yang menyusuh untuk segera kerja; dusun = bapak), kono nyambut gawe kono! Ning kabeh wisan, sak keluarga wis ngomong, kono lek kerjo, lek nganu, sek! Aku ngono haha," (Wahyu, wawancara 2018)

[Iya dusun bilang sana cari kerja! kalau semua sudah, sekeluarga bilang, sana kerja, kalau saya bilang bentar! Saya gitu haha]

Dalam wawancara mendalam dijelaskan bahwa ayahnya juga menganggap bahwa Wahyu masih belum mandiri karena masih bergantung pada orang tua. Setiap kegiatan di Ansor, Wahyu masih minta uang saku kepada ibunya. Saat ini di sela-sela kegiatan di Ansor, Wahyu memang ikut membantu ibunya berjualan di warung. Dalam prosesnya, kesulitan untuk membagi waktu antara bekerja dan kegiatan sosial ini juga tidak hanya membawa implikasi pada pekerjaan, keaktifan Wahyu di organisasi Ansor juga turut membawa pengaruh pada pandangan mengenai masa depannya. Ia menganggap bahwa profesi sebagai pengusaha adalah pekerjaan yang paling Jurnal Studi Pemuda 7(1), 2018 www.jurnal.ugm.ac.id/jurnalpemuda cocok masa depannya. sistem kerja pengusaha dianggap lebih fleksibel sehingga bagi Wahyu bisa mendukung kegemarannya beraktivitas di bidang sosial bersama GP Ansor. Secara spesifik dijelaskan dalam wawancara mendalam, Wahyu bercita-cita ingin membuka sebuah cafe yang menjual berbagai jenis kopi di masa depan.

Bryan

Bryan adalah pemuda berusia 19 tahun yang berasal dari Kota Semarang. Ia memiliki latar belakang pendidikan di SMK 8 Semarang jurusan rekayasa perangkat lunak. Setelah lulus, Bryan memutuskan untuk mencari pekerjaan. Namun, ia mengaku cukup kesulitan dalam mencari pekerjaan. Ia menjelaskan bahwa pernah mendaftar di beberapa perusahaan yang berkaitan dengan bidang IT, seperti paragon, DDS, telkomsel. Namun, Bryan belum mendapat pekerjaan tersebut. Menurutnya, ketidaksesuaian jurusan dengan posisi yang didaftar membuatnya tidak lolos dalam proses seleksi. Bryan memang sangat menyukai bidang IT, oleh karena itu, Bryan ingin sekali bekerja di bidang tersebut, sebagaimana dijelaskan dalam wawancara mendalam:

\footnotetext{
"Saya daftar, ternyata yang diminta dengan perusahaan itu tidak sesuai dengan kemampuan saya, beda bidang" (Bryan, wawancara 2018)
}

Dalam wawancara mendalam, Bryan menjelaskan bahwa ia mempunyai keinginan untuk melanjutkan studi di perguruan tinggi. Lebih lanjut dijelaskan pula bahwa Bryan juga telah mengetahui infomasi bagaimana mengakses perkuliahan secara gratis. Namun karena nilainya yang kurang, membuatnya tidak bisa mengikuti proses seleksi masuk perguruan tinggi melalui jalur tersebut. Untuk mengantisipasi risiko di masa depan, ia memutuskan untuk mencari pekerjaan setelah lulus SMK. Hal ini dilatarbelakangi oleh kondisi kondisi keluarganya yang tergolong miskin.

Bryan merupakan satu-satunya anak lakilaki di keluarganya. Statusnya sebagai anak laki-laki tidak membatasi Bryan untuk mengakses pekerjaan di luar kota. Namun karena ayahnya telah meninggal, Bryan harus menggantikan peran ayahnya di dalam keluarga. Bryan menjelaskan bahwa keputusannya tidak mengambil pekerjaan di luar kota adalah untuk 
menemani ibunya. Statusnya sebagai sosok laki-laki dalam keluarga membuat Bryan juga harus bertanggung jawab untuk melindungi keluarganya, sebagaimana dijelaskan:

\section{"Boleh-boleh saja [kerja di luar kota] kalau sama orang tua, soalnya kan saya anak cowok juga jadi tidak apa-apa. Tapi sayangnya berat ninggalin, kan ayah sudah tidak ada, jadi saya yang jaga ibu" (Bryan, wawancara 2018)}

Sama halnya dengan Wahyu, Bryan juga aktif di beberapa komunitas dan organisasi. la aktif dalam komunitas Rekayasa Perangkat Lunak (RPL). Meskipun mengaku tidak begitu aktif, Bryan juga tercatat sebagai anggota komunitas gereja. Kedua bentuk keterlibatan dalam organisasi tersebut bagi Bryan dapat memperluas jaringan sosial untuk memperoleh pekerjaan dan juga sekaligus untuk mewadahi minatnya pada informasi teknologi (IT).

Diana

Diana adalah perempuan berusia 17 tahun dari Kabupaten Demak, Jawa Tengah. Meskipun usianya yang tergolong masih sangat muda, namun ia telah berstatus sebagai seorang istri. Setelah lulus SMA, Diana bersama dengan pasangannya memang memutuskan untuk menikah. Saat wawancara dilakukan dapat terlihat bahwa ia sedang mengandung anak pertamanya. Menurut stock of knowledge Diana, usia 17 tahun adalah usia yang ideal untuk menikah. Pandangan mengenai menikah muda ini tidak terlepas dari pengaruh kondisi sosio-kultural lingkungan Diana, sebagaimana dijelaskan:

"Kalau orang sini gitu mbak. Kalau 17 tahun itu waktunya nikah. Kalau 20 tahun itu udah terlalu tua. Apalagi udah 20 tahun keatas," (Diana, wawancara 2018)

Sebagaimana budaya patriarki yang masih melekat di sebagian besar wilayah Indonesia, setelah menikah Diana tidak mempunyai banyak kesempatan dan kebebasan dalam memilih pekerjaan. Statusnya sebagai seorang istri mengharuskannya untuk menghabiskan lebih banyak waktu di rumah. Di sisi yang lain, dominasi laki-laki juga terlihat dari sifat suaminya yang cemburuan, sehingga dalam kehidupan sehari-hari menambah hambatan kultural bagi Diana dalam mengakses pekerjaan, sebagaimana dijelaskan:
"Pernah di pabrik Wallet mbak tapi karena nikah jadi berhenti. Disuruh di rumah aja sama suami." (Diana, wawancara 2018)

Berbeda dengan perempuan di daerahnya yang bekerja di pabrik, aspirasi masa depan yang terdekat dan realistis bagi Diana yaitu hanya ingin berjualan siomay di depan rumahnya. Menurut Diana, pekerjaan berjualan siomay tidak hanya memenuhi kebutuhan untuk bertahan hidup (subsisten) keluarga namun juga untuk memenuhi tuntutan suaminya yang tidak memperbolehkan dirinya untuk bekerja di luar.

\section{ASPIRASI PEMUDA DAN REPRODUKSI SOSIAL}

Berorientasi ke masa depan adalah bagian dari proses berkehidupan yang dialami oleh setiap manusia. Dalam konteks ini, pemuda menjadi subjek yang tepat dalam memahami bagaimana masa depan secara dialektis dibentuk dan terbentuk. Cara pandang ini mengacu pada salah satu perspektif youth transition yang menjustifikasi bahwa pemuda adalah sebuah stage of life yang sedang mengalami masa kritis, pemuda dianggap sedang berada pada masa perjuangan untuk meraih kesuksesan tidak hanya dalam hal transisi di domain pendidikan, pekerjaan dan pernikahan (Furlong and Cartmel 2007) namun juga transisi menuju ke masa kedewasaan (Wyn and White 1997). Masa transisi inilah yang mendorong setiap pemuda selalu berpikir, merencanakan, bertindak, menetapkan tujuan, mengeksplorasi pilihanpilihan, membuat komitmen, dan mengembangkan diri berdasarkan harapan mereka pada masa depan. Sebagaimana dijelaskan oleh Adamson et al (2007) bahwa memimpikan dan merenungkan masa depan menjadi aktivitas dan masalah yang menonjol bagi kaum muda.

Lika liku transisi pada ketiga domain (pendidikan, pekerjaan, pernikahan) serta membayangkan, menetapkan, dan mengejar aspirasi masa depan juga sedang dialami oleh keempat informan dalam penelitian ini. Mereka berada pada masa transisi dan critical moments (Thomson et al 2002) untuk menegosiasikan kondisi yang dimiliki (existing condition) dengan aspirasi masa depan yang mereka inginkan. Ditegaskan oleh Turken et al (2016) bahwa aspek 
subjektif (pemaknaan) pemuda secara kuat berelasi dengan wacana dominan yang ada di masyarakat baik itu dalam hal politik, ekonomi, budaya maupun sosial; termasuk juga dengan konteks perubahan sosial (Sutopo 2014; Woodman and Wyn 2015). Dalam kasus empat informan di atas, kelas dan gender saling berkelindan dalam konteks yang berubah terutama dalam kondisi LMF menjadi faktor utama dalam membentuk pandangan mereka atas masa depan serta terciptanya reproduksi sosial di Jawa Tengah.

Dwyer dan Wyn (2001) menjelaskan bahwa kelas sosial dan gender menjadi faktor yang signifikan dalam penentuan pilihan atas kehidupan anak muda, tidak hanya pada masa sekarang namun juga terkait dengan peluang mobilitas sosial di masa depan. Dalam transisi pada domain pendidikan, misalnya, posisi kelas sosial berkaitan dengan aksesibilitas pemuda dalam memperoleh pendidikan yang lebih tinggi dan sesuai dengan perubahan zaman. Ball (2008) menegaskan bahwa sejarah kebijakan pendidikan berfokus pada serangkaian hubungan antara negara, ekonomi, dan kelas sosial. Sebagai dua sisi dari mata uang yang sama, dijelaskan bahwa hal ini menyangkut bagaimana pendidikan mampu mencerminkan kelas sosial, dan juga sebaliknya kelas sosial sebagai sarana dalam memperoleh akses pendidikan yang lebih tinggi dan berkualitas. Lebih lanjut, dalam konteks yang berubah terutama di era neoliberal dimana pasar kerja menjadi lebih fleksibel (Woodman and Wyn 2015), France and Roberts (2017) menjelaskan bahwa pemuda yang berpendidikan sekalipun tidak menjamin dalam memperoleh pekerjaan dengan upah tinggi jika mereka berasal dari kelas menengah dan menengah ke bawah. Menurut France and Roberts (2017), penghasilan orang tua menjadi salah satu faktor paling penting dalam menentukan lintasan karir masa depan dan peluang mendapatkan pekerjaan bagi pemuda setelah menyelesaikan pendidikan di tingkat Universitas. Pendapatan orang tua ini mampu memfasilitasi pemuda untuk mengakses layanan-layanan yang dapat meningkatkan skill (misalnya les bahasa atau komputer) maupun program magang berbayar. Proses ini sebagai bentuk akumulasi 'modal budaya, modal sosial sekaligus modal simbolik' yang dapat dan dibutuhkan untuk memberikan nilai tambah bagi pemuda dalam mengakses pekerjaan setelah lulus universitas. Peningkatan skill dan kapasitas dalam level individu untuk memenuhi permintaan pasar ini sebagaimana yang dituntut oleh diskursus neoliberalisme yang termanifestasi dalam LMF.

Dalam penelitian ini, keempat informan termasuk pada kategori pemuda kelas menengah ke bawah. Latar belakang orang tua dengan kategori miskin mengakibatkan baik Wahyu, Bryan, Anjarwati, maupun Diana hanya mampu mengakses pendidikan sampai ke jenjang SMA. Bahkan Anjarwati harus putus sekolah dan melanjutkan pendidikan melalui program Paket C. Dengan kualifikasi pendidikan yang hanya sampai pada jenjang SMA, maka secara objektif tidak banyak variasi pekerjaan terutama yang menjanjikan pekerjaan tetap dan jaminan sosial yang memadai yang dapat terakses oleh para informan. Di sisi yang lain, keterbatasan ekonomi keluarga juga membuat para informan tidak mampu untuk meningkatkan dan "meng-upgrade" skill-skill yang diinginkan oleh pasar seperti mengakses pelatihan, program-program magang, maupun layananlayanan lain. Dengan kata lain, secara teoritis dapat dijelaskan bahwa kelas sosial (France and Roberts 2017) menjadi faktor penting terciptanya reproduksi sosial dalam hal ini terkait dengan aspirasi dan harapan masa depan pemuda. Di sisi yang lain, konteks yang berubah (Sutopo 2014; Woodman and Wyn 2015) juga menjadi faktor penting dimana reproduksi sosial berdasarkan kelas beroperasi secara berbeda; dalam kasus ini ditunjukkan pada ketidakmampuan informan untuk meng-upgrade kapital budaya yang relevan dengan rule of the game pasar kerja yang bercorak neoliberal.

Dalam studi ini, selain kelas sosial, gender juga menjadi komponen penting dalam membentuk pandangan masa depan para informan dan terciptanya reproduksi sosial di Jawa Tengah. Argumen ini mengacu pada bagaimana pemuda menegosiasikan identitas gendernya dengan konstruksi sosial yang melekat dalam ranah perjuangan dimana mereka hidup, sebagaimana dijelaskan Dwyer dan Wyn (2001) bahwa "Gender therefore remains powerful in structuring the conditions under which young people form 
and negotiate their identities". Dalam konteks Indonesia, keterlekatan gender dengan kesempatan serta kebebasan pilihan-pilihan kerja merupakan dua variabel yang masih sangat terkait satu sama lain. Konstruksi mengenai "kodrat" perempuan (Partini 2013) yang tidak boleh jauh dari rumah, tanggung jawab perempuan setelah menikah, dan laki-laki sebagai tulang punggung keluarga misalnya, masih memengaruhi dan membatasi pilihan-pilihan para informan dalam mengakses kerja dan menentukan masa depannya (Nilan 2008; Parker and Nilan 2013).

Masih kuatnya keterkaitan antara gender dan kesempatan serta pilihan-pilihan kerja di masa depan dalam penelitian ini terjadi pada kasus Anjarwati dan Diana. Sebagai anak perempuan, Anjarwati tidak leluasa memilih kota tujuan untuk bekerja. Ia hanya diperbolehkan bekerja di wilayah yang tidak jauh dari rumahnya. Di sisi lain, sebagai seorang istri, dalam kondisi kesenjangan gender yang masih dianggap "normal", mengharuskan Diana untuk tetap tinggal di rumah. Keterbatasan ruang akses baik secara spasial maupun kesempatan kerja bagi mereka, mengakibatkan Anjarwati dan Diana memfokuskan aspirasi masa depan pada apa yang dekat dengan mereka serta berusaha menegosiasikan dan mewujudkannya semaksimal mungkin. Untuk mematuhi suami dan memenuhi kebutuhan subsisten serta kelangsungan masa depannya, Diana beranggapan bahwa berjualan siomay di depan rumah adalah pekerjaan yang cocok, realistis dan menjadi semacam "win-win solution" dalam usahanya mencari jalan tengah antara tekanan struktural dan kultural yang dihadapinya. Kasus serupa juga terjadi pada Anjarwati, larangan dari keluarga untuk bekerja di luar kota mengakibatkan dirinya memusatkan aspirasi masa depan pada pekerjaan-pekerjaan yang ada di sekitar rumahnya.Berdasarkan data sekunder, dapat dijelaskan bahwa Anjarwati tinggal di Kabupaten Semarang tepatnya di Kecamatan Bergas dimana setidaknya terdapat 50 pabrik dengan skala besar dan sedang antara lain: P'T. Sinar Sosro, P'T. Sido Muncul, dan P'T. Morich Indo Fashion (BPS 2015). Kondisi ini menjadi salah satu faktor yang memberikan dorongan bagi Anjarwati dalam menentukan aspirasi mengenai masa depannya. Anjarwati ingin bekerja di pabrik besar dengan gaji tetap. Di sisi lain, penentuan aspirasi masa depannya juga didorong oleh taken for granted knowledge bahwa teman-teman perempuannya dianggap lebih "mapan" ketika telah bekerja di pabrik besar. Secara teoretis dapat dijelaskan bahwa diskursus neoliberalisme melalui penerapan LMF seakan-akan memberikan kesempatan yang sama bagi laki-laki dan perempuan dalam melakukan mobilitas sosial dalam ranah pekerjaan, namun yang terjadi dalam kasus informan penelitian ini adalah faktor gender (Wyn et al 2017) masih berpengaruh dalam penentuan aspirasi masa depan mereka. Di sisi lain, backround kelas bawah informan menjadi hambatan sruktural yang semakin meneguhkan kesenjangan gender dikarenakan keputusan untuk bekerja bagi perempuan bukan berdasarkan pilihan namun justru hasil negosiasi untuk memenuhi kebutuhan subsisten keluarga sekaligus tuntutan untuk menjadi "perempuan yang baik" di mata masyarakat dimana mereka hidup. Dengan kata lain, dapat disimpulkan bahwa aspek kelas sosial, gender dan konteks yang berubah saling berkelindan dan beririsan satu sama lain dalam menciptakan reproduksi sosial di Jawa Tengah.

\section{KESIMPULAN}

Keempat narasi mengenai transisi dan aspirasi masa depan pemuda di Jawa Tengah yang telah dipaparkan di atas menunjukkan bahwa proses transisi tidak pernah berjalan secara linear dan lancar. Dalam era neoliberalisme dan secara spesifik penerapan LMF tidak serta merta memberikan kesempatan yang lebih baik bagi pemuda dalam menempuh transisi menuju ke dunia kerja. Dalih neoliberalisme akan kesempatan yang sama bagi pemuda dari semua lapisan sosial terhadap gakses pekerjaan tidak pernah terjadi pada kasus keempat informan dalam penelitian ini. Yang terjadi justru background kelas sosial masih menjadi faktor yang relevan dalam mempengaruhi proses transisi dan aspirasi pemuda Jawa Tengah di masa depan.

Narasi mengenai transisi dan aspirasi pemuda Jawa Tengah mengenai masa depan juga menunjukkan bahwa selain kelas sosial, aspek gender juga masih menjadi faktor yang berpengaruh kuat. 
Sebagai perempuan, tuntutan untuk tidak perlu menempuh pendidikan terlalu tinggi, hanya boleh bekerja di daerah sekitar, menikah di usia muda, mempunyai anak, dan menuruti keinginan suami masih menjadi narasi dominan yang terus menerus direproduksi dalam transisi dan aspirasi pemuda. Di sisi yang lain, background kelas bawah juga beririsan secara kuat dengan aspek gender untuk semakin meneguhkan posisi marjinal pemuda Jawa tengah. Narasi mengenai transisi dan aspirasi masa depan pemuda Jawa Tengah juga menunjukkan bagaimana konteks yang berubah menjadi faktor yang berpengaruh. Dalam konteks yang berubah terutama era neoliberalisme dan LMF, tidak semua pemuda mendapatkan kesempatan yang sama dalam menempuh transisi menuju dunia kerja dan menggapai aspirasi ideal yang diharapkan dimasa depan. Yang terjadi justru reproduksi sosial berdasarkan kelas dan gender masih terus menerus dipertahankan serta memungkinkan kesenjangan sosial akan semakin meningkat di masa depan.

\section{DAFTAR PUSTAKA}

Adamson, L., Ferrer-Wreder, Laura, and Kerpel men, Jennifer. 2007. "Self-Concept Consistency And Future Orientation During The Transition To Adulthood". Young 15(1): 91-112.

Andres, L. and Wyn, J. 2010. The making of a generation: the children of the '70s in adulthood. Toronto University Press: Toronto.

Allen, Emma R. 2016. Analysis of Trend and Chal-lenges in The Indonesian Labor Market. ADB Papers on Indonesia No.16. Manila: Asian Development Bank.

Ball, Stephen J. 2008. The Education Debate. UK: The Policy Press.

Beck, Ulrich. 2014. The Brave New World of Work. German: Polity Press.

Dwyer, Tom, Mikhail Gorskhov, Ishwar Modi et al. 2018. Handbook of the sociology of youth in BRICS countries. USA: World Scientific.
Dwyer, Peter and Wyn, Johanna. 2001. Youth, Education and Risk: Facing the Future. USA: Routledge.

Furlong, Andy \& Cartmel, Fred. 2007. Young People and Social Change: New Perspectives. USA: Open University Press.

France, Alan and Roberts, Steven. 2017. Youth and Social Class Enduring Inequality in the United Kingdom, Australia and New Zealand. London: Palgrave.

Harvey, David. 2005. A Brief History of Neoliberalism. New York: Oxford University Press.

Heath, Sue, Rachel Brooks, Elizabeth Cleaver et al. 2009. Researching young people's lives. London: Sage.

Indrawan, Aditya. 2017. "Pemuda Indonesia Meningkat, Angka Pengangguran Bertambah”. Detiknews. Diakses pada 20 April 2018 (https:// news.detik.com/berita/3699632/pemuda-indonesia-meningkat-angka-pengangguran-bertambah)

Kartika, Desta. 2018. "Juli 2018, Nilai Investasi Masuk Jawa Tengah Mencapai 27,6 Triliun”. Tribun Jateng. Diakses pada 10 November 2018 (http://jateng.tribunnews.com/2018/10/09/ juli-2018-nilai-investasi-masuk-jawa-tengah-mencapai-276-triliun)

Kelly, Peter. 2006. "The entrepreneurial self and 'youth at-risk': Exploring the horizons of identity in the twenty-first century". Journal of youth studies 9 (1): 17-32.

Leavy, Patricia. 2014. Introduction. In Leavy (Ed). Oxford Handbook of Qualitative Research. New York: Oxford University Press.

Minza, Wenty Marina. 2014. Masa Muda Sebagai Masa Transisi. In Azca, M Najib, Derajad S.Widhyharto and Oki Rahadianto Sutopo (Eds) Buku Panduan Studi Kepemudaan: Teori, Metodologi, dan Isu-isu Kontemporer. Yogyakarta: Youth Studies Centre Fisipol UGM.

Naafs, Suzanne. 2018. "Youth Aspirations And Employment In Provincial Indonesia: A View From The Lower Middle Classes". Children Geographies 16(1): 53-65. 
Nilan, Pam. 2008. "Youth Transitions to urban, middle class marriage in Indonesia: Faith, Family and Finances". Journal of Youth Studies 11(1): $65-82$.

Nilan, Pam, Parker, L., Bennett, L. and Robinson, K. 2011. "Indonesian Youth Looking Towards the Future". Journal of Youth Studies 14(6): 709-728.

Nilan, Pam and Luh Putu Artini. 2013. "Motivasi, Pengalaman dan Harapan kaum Muda Bali bekerja di kapal Pesiar". Jurnal Studi Pemuda 2(1): 75-89.

Parker, Lyn and Pam Nilan. 2013. Adolescent in Contemporary Indonesia. London: Routledge.

Partini. 2013. Bias Gender dalam Birokrasi. Yogyakarta: Tiara Wacana.

Purdy, David. 1988. Social Power and the Labour Market. London: Macmillan.

Sutopo, Oki Rahadianto. (2014). Perspektif Generasi dalam Kajian Kepemudaan, chapter buku dalam Azca, M. Najib, Derajad S. Widhyharto \& Oki Rahadianto Sutopo (Eds). Buku Panduan Studi Kepemudaan: Teori, Metodologi dan Isu-Isu Kontemporer. Yogyakarta: Youth Studies Centre Fisipol UGM.

Sutopo, Oki Rahadianto dan Nanda Harda Pratama Meiji. 2014. "Transisi Pemuda Dalam Masyarakat Risiko: Antara Aspirasi, Hambatan dan Ketidakpastian”. Jurnal Universitas Paramadina 11 (3): 1164-1186.

Standing, Guy. 2014. "Understanding the Precariat through Labour and Work". Development and Change 45(5): 963-980.
Thomson, R, Robert Bell, Janet Holland et al. 2002. "Critical Moments: Choice, Chance And Opportunity In Young People's Narratives Of Transition". Sociology 36(2): 335-354.

Turken, Salman et al. 2016. "Youth's Future Orientation and Well-Being: Materialism and Concerns with Education and Career among Turkish and Norwegian Youth". International Journal of Child, Youth and Family Studies, 7 (3/4): 472-497.

Utari, Fatimah. 2018. "Di Jateng, Ada 1,5 Juta Pemuda Menggangur". KrJogja. Diakses pada 23 Maret 2018 (https://krjogja.com/web/news/

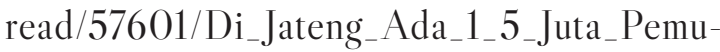
da_Menganggur)

Woodman, Dan, Threadgold, Steven, and Alphia Possemei-Inesedy. 2015. "Prophet of a new modernity: Ulrich Beck's legacy for sociology. Journal of Sociology 51(4): 1117-11131."

Woodman, Dan and Wyn, Johanna. 2015. Youth and Generation Rethinking change and inequality in the lives of young people. London: Sage.

Wyn, Johanna, Hernan Cuervo, Jessica Croft and Dan Woodman. 2017. "Gendered Transitions from School to Work: The Mysterious Relstionships Between The Fields Of Education And Work". Journal of Sociology 53(2): 492506.

Wyn, Johanna and White, Rob. 1997. Rethinking Youth. London: Sage. 